Научная статья /

Research Article

УДК 8II.I4.0

ББК 83.3(4Гре)
ПУТЕВЫЕ ЗАМЕТКИ Н. КАЗАНДЗАКИСА

И К. УРАНИСА В КОНТЕКСТЕ

НОВОГРЕЧЕСКОЙ ЛИТЕРАТУРЫ

О ПУТЕШЕСТВИЯХ

\author{
(C) 2021 г. О.Б. Боброва \\ Независимый исследователь, Москва, Россия \\ Дата поступления статьи: І4 января 202І г. \\ Дата одобрения рецензентами: Іо марта 2021 г. \\ Дата публикации: 25 сентября 2021 г. \\ https://doi.org/IO.22455/2500-4247-202I-6-3-96-II5
}

Аннотация: Никос Казандзакис - один из самых значительных греческих авторов $\mathrm{XX}$ столетия, известный главным образом своими крупными прозаическими произведениями. Романы Н. Казандзакиса признаются критикой

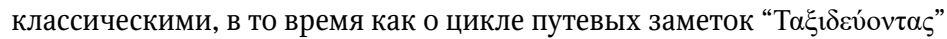
(«Путешествуя»), составляющих заметную часть его литературного наследия, в настоящее время трудно сказать нечто определенное, поскольку спектр оценок исследователей простирается от нейтральных или сдержанно-негативных до восторженных, а высказываемая при этом точка зрения нередко не подкрепляется сколько-нибудь распространенным анализом художественных особенностей цикла. В работе предпринята попытка представить более обоснованную и мотивированную оценку цикла путевых заметок Н. Казандзакиса и его роли в развитии жанра травелога. Показано, в частности, что, вопреки распространенной в современной критике точке зрения, жанр путевых заметок в новогреческой литературе начал формироваться задолго до появления травелогов Н. Казандзакиса и что значительный вклад в его развитие внесли предшественники и современники Н. Казандзакиса. Среди последних следует особенно выделить Костаса Ураниса, поскольку в его путевых заметках разрабатываются и развиваются некоторые из черт, обнаруживаемых в дальнейшем в травелогах Н. Казандзакиса.

Ключевые слова: новогреческая литература, путевые заметки, травелог, Никос

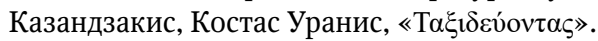

Информация об авторе: Ольга Борисовна Боброва - кандидат филологических наук, независимый исследователь, г. Москва, Россия. ORCID ID: https://orcid.org/00oo-0002-9824-4518

E-mail: boberdober88@mail.ru

Для цитирования: Боброва О.Б. Путевые заметки Н. Казандзакиса и К. Ураниса в контексте новогреческой литературы о путешествиях // Studia Litterarum. 2021. T. 6, № 3. С. $96-115$.

https://doi.org/IO.22455/2500-4247-202I-6-3-96-II5 


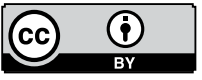

This is an open access article distributed under the Creative Commons Attribution 4.0 International (CC BY 4.0)

Studia Litterarum, vol. 6, no. 3, 202I

\section{NIKOS KAZANTZAKIS' AND KOSTAS OURANIS' TRAVEL WRITINGS WITHIN THE CONTEXT OF MODERN GREEK TRAVELOGUES}

(C) 202I. Olga B. Bobrova

Independent researcher, Moscow, Russia

Received: January I4, 202I

Approved after reviewing: March IO, 202I

Date of publication: September 25, 202I

Abstract: Nikos Kazantzakis is one of the most famous Greek authors of the $20^{\text {th }}$ century known primarily for his novels. A significant part of Nikos Kazantzakis's work is his travel writings. Whereas the novels of Kazantzakis are recognized as canonical

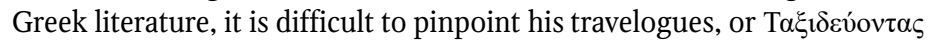
(Traveling) due to the ambiguity of their critical reception: assessments range from neutral or mildly negative to enthusiastic. Both critical and enthusiastic assessments usually lack in-depth analysis of poetic, thematic, compositional, and stylistic features of the Traveling cycle. This essay is an attempt at a more cogent and motivated assessment of Kazantzakis's cycle of travel notes and his role in the development of this genre. In contrast to the general view in Greek criticism, I argue that the genre of travelogue had developed for an extended period before Traveling was published and that Kazantzakis's predecessors and contemporaries had contributed to its development. Among them is Kazantzakis's contemporary Kostas Ouranis whose work has aspects and features to be found in the later work of Kazantzakis as the comparative analysis of the travel notes by both authors demonstrates.

Keywords: Modern Greek literature, travel writings, travelogue, Nikos Kazantzakis,

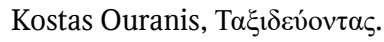

Information about the author: Olga B. Bobrova, $\mathrm{PhD}$ in Philology, Independent Researcher, Moscow, Russia.

ORCID ID: https://orcid.org/oooo-0002-9824-45I8

E-mail: boberdober88@mail.ru

For citation: Bobrova, O.B. "Nikos Kazantzakis' and Kostas Ouranis' Travel Writings within the Context of Modern Greek Travelogues." Studia Litterarum, vol. 6, no. 3 , 202I, pp. 96-II5. (In Russ.)

https://doi.org/IO.22455/2500-4247-202I-6-3-96-II5 
Никос Казандзакис (I883-I957) - один из самых известных греческих авторов XX столетия, девять раз номинированный на Нобелевскую премию по литературе. Поэт, прозаик, драматург, философ, просветитель, общественный и политический деятель, переводчик, журналист и редактор, Казандзакис снискал славу не только в Греции, но и за рубежом, что само по себе - редкий случай в истории греческой словесности. Это оказалось возможным в первую очередь благодаря многочисленным переводам ${ }^{\mathrm{I}}$ круп-

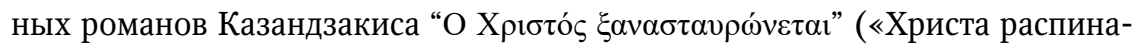

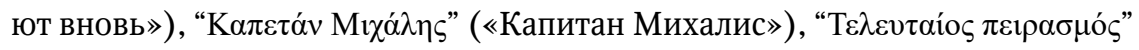

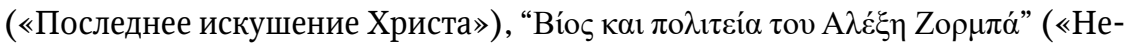
вероятные похождения Алексиса Зорбаса», «Я, грек Зорба», «Грек Зорба»)². Немалую роль в популяризации творчества Казандзакиса сыграла и массовая культура, а именно фильмы, снятые по сюжетам его романов [«Тот, кто должен умереть» Ж. Дассена (г957), «Грек Зорба» М. Какоянниса (1964), «Последнее искушение Христа» М. Скорсезе (І988)].

В силу ряда обстоятельств некоторые большие прозаические произведения Казандзакиса были изданы в Греции позднее, чем их иностранный перевод. На родине автор долгое время был известен в первую очередь как

I По некоторым данным, Н. Казандзакису принадлежит титул самого переводимого греческого автора [см., например: https://www.sansimera.gr/biographies/203 (дата обраще-

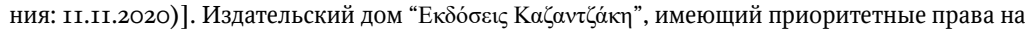
публикацию произведений Н. Казандзакиса, сообщает о 580 переводах его работ на разные языки [см.: http://www.kazantzakispublications.org/files/Translations.pdf (дата обращения: I7.II.2020)].

2 Все перечисленные произведения, кроме романа «Капитан Михалис», доступны в переводе на русский язык. В скобках приводятся названия романов в том виде, в каком они выходили в русском переводе. 
журналист и автор путевых заметок [7, с. І6], т. е. произведений художественно-публицистических, которые с точки зрения современного литературоведения уступают «благородному» жанру романа, поскольку рассматриваются как проба пера для авторов «второго ряда» или выдающихся писателей в самом начале творческой деятельности [5, с. 28I].

Окончательно расставив приоритеты и признав безусловную художественную ценность романов Н. Казандзакиса, современная греческая критика чаще всего рассматривает его путевые заметки как некий второстепенный придаток к другим поэтическим и прозаическим произведениям [І3, с. 8о]. При этом, однако, некоторые исследователи не устают подчерки-

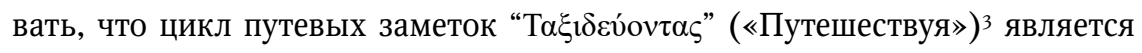
«первой достойной книгой путевых заметок в новогреческой литературе» $[24$, c. 72$]$ и занимает важное место не только в греческой, но и в европейской словесности [I5, с. 27I; 25, с. 34], что речь идет об «истинно художественных произведениях, в которых искусство слова сочетается с историей, эстетикой, этнографией, мифом и драмой» [25, с. 245]. Эти восторженные оценки, оспаривающие «вторичность» путевых заметок Казандзакиса, тем не менее не всегда подкрепляются сколько-нибудь распространенным анализом художественных, тематических, композиционных и стилистиче-

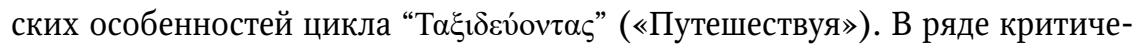
ских статей, посвященных циклу путевых заметок Н. Казандзакиса, вовсе не рассматривается история травелога в греческой литературе, хотя обращение к ней объяснило бы, за счет чего произведения, входящие в цикл “Т $\alpha \xi 1 \delta \varepsilon v ́ o v \tau \alpha \varsigma ”$ («Путешествуя»), могут быть отнесены к числу выдающихся образцов этого жанра.

Очевидно, что «первая достойная книга путевых заметок в новогреческой литературе» не могла появиться из ничего и не может в той или иной степени не опираться на предшествующую литературную традицию, греческую и европейскую. Помимо этого, всякое произведение словесности существует в некотором историческом и литературном контексте, без рассмотрения которого любые рассуждения о его художественной ценности выглядят голословными.

3 На данный момент в переводе на русский язык опубликован лишь небольшой фрагмент путевых заметок Н. Казандзакиса (см.: [26]). Далее в тексте статьи во избежание разночтений название цикла и его отдельных книг приводится по-гречески с дословным переводом. 
Учитывая вышесказанное, в настоящей работе предполагается кратко рассмотреть историю формирования и развития путевых заметок в новогреческой литературе, а также сопоставить записки Казандзакиса с некоторыми другими произведениями того же жанра, созданными его современниками. Особенно интересны в этом смысле травелоги К. Ураниса, поскольку, по мнению ряда исследователей, именно этому автору, не снискавшему, в отличие от Н. Казандзакиса, мировой известности, удалось сделать путевые заметки полноценным жанром художественной литературы. Думается, что такой подход позволит не только отдать должное незнакомым широкой публике заметкам К. Ураниса, но и более конкретно определить литературно-художественную ценность травелогов Н. Казандзакиса.

Любопытство и интерес к дальним и неизвестным странам присущи человеку на протяжении всей его истории, и в этом смысле первым образцом литературного жанра путешествия в европейской традиции можно считать эпическую поэму Гомера «Одиссея» [Iо, с. XIII; I7, с. 23]. На том же основании к литературе этого рода нередко относят и такие, казалось бы, несхожие между собой произведения, как «Энеида» Вергилия, труды Страбона по географии, исторический трактат Геродота и сочинения Ксенофонта [ІІ, с. 45].

Появление жанра путешествий в Европе связано в первую очередь с активизацией контактов с иноязычными народами. Записки путешественников в дальние страны начинают систематически печататься с середины XVI в. [I, с. 3I5]. В дальнейшем их сюжетно-композиционные приемы и особенности содержания активно осваиваются художественной литературой [I, с. 315].

На рубеже XVIII-XIX вв. ориентация на субъективность и связанная с этим «смена парадигмы» в литературе привела к появлению жанра писательского путевого очерка. Тенденция объективного описания реальных событий и автобиографичности дополняется противоположной ей тенденцией субъективно-ориентированного изображения действительности [I, с. 3I5], которая на протяжении XIX в. постепенно становится преобладающей. По мере приближения к современности в фокусе повествования все чаще оказывается сам рассказчик, а на первый план выходит не объективная реальность, а ее восприятие через призму авторского «я» $[8$, с. 3$]$. 
Драматические события истории $\mathrm{XX}$ в. привносят в путевые заметки новые мотивы: путешествие начинает рассматриваться авторами путевых заметок как особая форма эскапизма [I, с. 315]. Новшеством путевых заметок второй половины XX столетия становится окончательное размывание границ реального и ирреального, фактического и выдуманного не только в путевых заметках, но и в других повествовательных жанрах [І2, с. Iо6]. В этот период в литературных путешествиях ярко проявляются модернистские черты: традиционно характерное для этого жанра объективное и почти обезличенное повествование о событиях, хронологически следующих одно за другим, сменяется отрывочным, нередко фрагментарным и сбивчивым автобиографическим рассказом, в центре которого - сам автор и занимающие его психологические и социальные вопросы [8, с. 3-4].

Относительно недавно для обозначения литературы о путешествиях в литературоведении начал использоваться термин «травелог», аналогичный понятиям «путевые заметки», «путевые записки», «путешествие» [2, с. 3]. В настоящее время травелог рассматривается как многоплановый синтетический жанр, находящийся на грани между искусством и наукой, литературой и публицистикой, личным и социальным, объективным и субъективным [5, с. 278]. К числу его характерных (т. е. жанрообразующих) черт следует отнести, во-первых, структурообразующую роль автора в тексте [5, с. 28о]. Автор является одновременно и главным героем, и основной движущей силой сюжета; от автора же зависит и степень субъективности повествования: по воле пишущего изображение событий может быть как максимально объективным, так и далеко отстоять от реальности [2I, с. II].

Во-вторых, путешествие обязательно включает в себя элементы других жанров, как художественных, так и небеллетристических [5, с. 28I]. Его «литературность» проявляется в субъективности взгляда рассказчика, возможном заимствовании художественных приемов и особенностях стиля, в то время как публицистичность является способом выражения авторской позиции [5, с. 28I] и связана с тем, что путешествие может ставить перед собой различные цели, например, информационные, политические, философские, агитационные и т. д. [I, с. 3I4]. Кроме того, в отличие от художественной литературы, путешествие имеет тесную связь с внелитературной действительностью и нередко является «откликом на запросы аудитории» [5, с. 28I]. 
В греческой литературе развитие жанра путешествий происходило в целом в общеевропейском русле. Самые ранние образцы жанра, написанные на греческом языке, - описания путешествий в византийской агиографии, а также разнообразные хожения и паломничества - во многом опирались на библейские и античные образцы [3, с. 3]. Для образованных греков, живших в Османской империи, а позднее и для подданных независимого греческого государства были доступны многочисленные путешествия, путевые заметки, отчеты и записки, издававшиеся на европейских языках.

По всей видимости, именно под влиянием зарубежных авторов в новогреческой литературе путешествие начинает складываться как самостоятельный жанр. По мнению литературоведа Э. Хурмузиоса, особую роль в его становлении на греческой почве сыграли путевые заметки Стендаля («Рим, Неаполь и Флоренция» (І8І8), «Прогулки по Риму» (І829), «Записки туриста» (І838)) и «Путешествия по Италии» И. Тэна (І866) [25, с. 244].

О росте популярности жанра путешествия во второй половине XIX в. свидетельствует обилие отчетов, записок и путевых заметок (как переводных, так и оригинальных), выходивших в греческой периодической печати [2I, c. II]. Отметим, что на этот период приходится и формирование национального самосознания в Греции - стране, относительно недавно получившей независимость от Османской империи и остро ощущавшей необходимость в национальной идеологии [4, с. 326]. На фоне поиска собственной национальной идентичности в Греции развиваются историография и этнография, активно изучаются устное народное творчество, обычаи, традиции и диалекты различных областей, а главенствующим жанром в

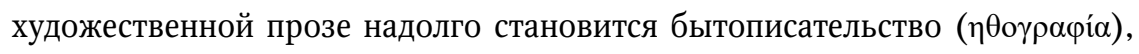
т. е. «детальное изображение небольшого более или менее современного традиционного сообщества в его естественной среде» [6, с. Іо7]. Очевидно, что путешествие как способ познания себя и своего народа отвечало чаяниям просвещенной публики, что подтверждается тем, что произведения в жанре путевых заметок создавали в тот период многие выдающиеся авторы, например, Димитриос Викелас, Александрос Ризос-Рангавис, Иоаннис Кондилакис, Георгиос Дросинис, Андреас Каркавицас [2I, с. І2].

С постепенным угасанием романтизма (І88о-е гг.) и до Первой мировой войны путевые заметки на греческом языке выходят в печати спорадически $[24$, c. 67]. В период же между Первой и Второй мировой войной 
в Греции вновь наблюдается рост читательского интереса к литературе о путешествиях. Связано это в первую очередь с тем, что, несмотря на многочисленные технические достижения XX столетия (например, радио), печать оставалась единственным бесперебойным источником информации об окружающем мире, других странах и народах. Сведения же такого рода в эпоху изменений и глобальных катаклизмов представляли особый интерес [23, C. I2].

Установление модернизма как главенствующего направления в литературе повлекло за собой изменения и в жанре путешествия: на первый план выходит авторское «я», и именно эта вездесущая авторская личность отныне определяет выбор «оптики» для описания действительности [2I, c. I2-I3]. В результате жанр, при рождении своем бывший, скорее, историей, претендовавшей на полное соответствие действительности, окончательно превращается в литературу (т. е. вымысел, fiction).

Цикл путевых заметок Н. Казандзакиса родился из впечатлений и наблюдений автора, сделанных им в период с г920 по г939 г. во время поездок как по Греции, так и за рубеж в статусе специального корреспондента крупных греческих газет [15, с. 272]. Первым длительным путешествием становится поездка в Россию в І925 г., за ней следуют поездки в Италию (1926), Палестину и Египет (1926). На обратном пути из Палестины Н. Казандзакис совершит краткую поездку на Кипр, а в следующем году - на Синай (1927). В том же г927 г. Н. Казандзакис вновь отправляется в Советский Союз и остается в этой стране до начала 1929 г. Позднее писатель также совершит поездки в Испанию (1932 и І933), Японию и Китай (1935), в очередной раз в Испанию, но уже в разгар гражданской войны (1936), на Пелопоннес (1937), в Англию (1939) [20, с. 40]. Путевые заметки, являясь живым и непосредственным откликом на значительные события и политические потрясения, первоначально публикуются в афинской прессе и приносят автору известность [I5, c. 272]. В дальнейшем эти материалы, в той или иной степени переработанные и тематически сгруппированные, выйдут в свет в виде серии отдельных

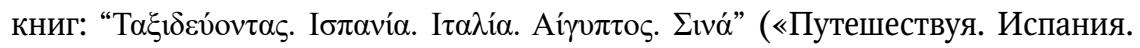

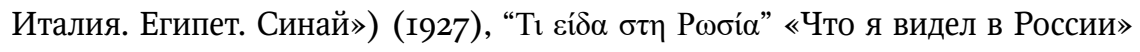

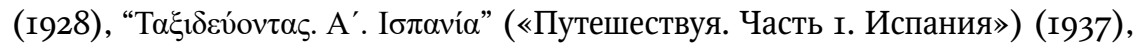

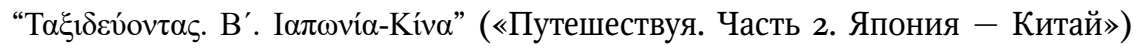

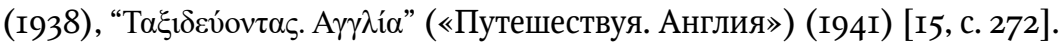


Среди греческих исследователей литературы распространено мнение, что именно Н. Казандзакису удалось превратить путевые заметки в полноценную литературную форму [7, с. I7; 2I, с. I3]. Как показал приведенный выше краткий обзор формирования и развития травелога в греческой литературе, к моменту публикации первых заметок Н. Казандзакиса этот жанр имел длительную историю и, кроме того, в нем работали не только «авторы второго ряда», но и выдающиеся писатели-прозаики.

Не следует также упускать из виду и того, что для развития жанра травелога многое было сделано и современниками Н. Казандзакиса, среди которых в первую очередь стоит упомянуть о Костасе Уранисе (І890-I953), поэте, критике, переводчике и журналисте, который с г919 г. (т. е. несколькими годами раньше, чем Н. Казандзакис) начинает систематически публиковать в печати корреспондентские заметки о поездках как по Греции, так и за ее пределами. Позднее сборники тематически сгруппированных путевых заметок К. Ураниса выходили отдельными книгами под общим заголовком

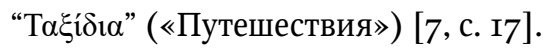

По мнению Ф. Пилариноса, именно К. Ураниса следует считать законодателем жанра путешествия в греческой литературе [22]. Того же мнения придерживается и Я. Кордатос, отмечая, что путевые заметки писали многие авторы и до К. Ураниса, но, в отличие от них, его впечатления и описания можно считать настоящей литературой [18, с. 649].

Рассмотрим, что же делает путевые заметки К. Ураниса «настоящей литературой», а его самого, таким образом, - предтечей Н. Казандзакиса на этом поприще.

С точки зрения формы и внутреннего построения сюжета путевые заметки Ураниса производят впечатление хаотичности, отрывочности и некоторой небрежности [22]. Причины такой организации отчасти следует искать в том, что первоначально каждая из заметок представляла собой самостоятельную, ограниченную по объему единицу текста, предназначенную для публикации в периодической печати. Включенные в сборник, эти материалы претерпели лишь незначительные изменения.

Помимо этой чисто внешней мотивировки, такая «дезорганизация», безусловно, связана и с глубинными мировоззренческими установками автора, для которого на первом месте и в прозе, и в поэзии стояло «непосредственное выражение чувства» [14, с. 378], а не форма этого выражения. 
Теми же причинами, по всей видимости, объясняется и то, что описания локаций, пейзажей и людей в прозе К. Ураниса импрессионистичны по своей природе: автор, не отвлекаясь на поверхностное и кажущееся и не увлекаясь описаниями ради описания, которыми изобилуют произведения его предшественников, пытается как будто увидеть описываемое изнутри, проникнуть в суть происходящего, понять скрытые мотивы героев [22].

Показательно в этом смысле, например, такое описание города Митилена (о-в Лесбос):

Митилена - один из самых многогранных городов, которые я только видел ${ }^{4} .$. Она заключает в себе три города: восточный, греческий и европейский, и каждый - со своим особенным характером. «Греческий» город - город банков, контор, учреждений, город торговый и портовый, город кофеен... - город некрасивый. Здание театра здесь больше бы подошло для склада древесины, в городском парке деревьев меньше, чем стульев в кофейнях поблизости... Это город, который только готовится стать городом...

«Европейский» квартал составляют прекрасные виллы, взбирающиеся по склону горы... Повернув голову, ясно видишь малоазиатские пятна домов небольшого городка, который до катастрофы был населен сплошь греками. Как глубока печаль и как сильна мука десятков тысяч беженцев, которые живут сегодня в Митилене, когда они каждый день видят напротив, так близко, землю своих предков и своих могил... И, как будто этой моральной пытки недостаточно, многие из этих несчастных людей влачат здесь жизнь, полную страха и унижений, потому что вопрос с расселением беженцев пока не решен 5 [31, с. 96].

Как видно из приведенного отрывка, описание, не лишенное интереса и выразительности, для К. Ураниса ценно не только и не столько как пейзажная зарисовка. Как в лучших произведениях психологической прозы, оно откликается на внутренние ощущения и чувства героев (в приведен-

4 Здесь и далее цитаты приводятся в переводе автора статьи.

5 Речь идет о событиях так называемой малоазиатской катастрофы (І922). В ходе военной кампании I920-I92I гг., имевшей целью возвращение Греции территорий Малой Азии, населенных этническими греками, греческая армия потерпела поражение, за которым последовал обмен населением между Турцией и Грецией, погрузивший последнюю в глубочайший гуманитарный и политический кризис [4, с. 514, 516]. 
ном отрывке это сам автор). Контраст богатых «европейских» кварталов Митилены и временных поселений беженцев драматически подчеркивает трагедию тысяч людей, чьи страдания не исчерпываются изгнанием с земли предков: отделенные от побережья Малой Азии, своего прежнего дома, лишь узкой полоской моря, они еще и вынуждены смотреть, как в этом доме хозяйничает захватчик.

Приведенный отрывок также может рассматриваться в качестве иллюстрации того, как взаимодействует в прозе К. Ураниса «внешнее» и «внутреннее», объективное и субъективное. Рассматривая путешествие как бегство и попытку скрыться от жизни [31, с. 582], К. Уранис всегда выводит на первый план авторское «я». По его собственному признанию, не стоит искать в его прозе ничего, кроме субъективного [3I, с. 6]. По этой же причине, по всей видимости, он избегает традиционных местных «красот» и известных памятников, обязательных к посещению для иностранных туристов: гораздо большую ценность для него представляют собственные наблюдения и впечатления, связанные, казалось бы, с ничем не примечательными городскими улицами и пейзажами [22]. В то же время, как видно из приведенной выше цитаты, в отличие от других авторов-модернистов, К. Уранис не обходит молчанием болезненные вопросы и актуальные события эпохи, однако рассматривает их как своеобразный социально-политический фон для своих размышлений.

Преобладающую роль авторского «я», но при этом отсутствие абсолютной сосредоточенности на субъективном следует отнести к безусловным достоинствам путевых заметок Ураниса: помимо личных впечатлений и настроений, К. Уранис не чуждается отвлеченных философских рассуждений (например, о природе творчества или о том, что дает человеку путешествие). Являясь типичным «начитанным туристом» [22], автор также снабжает читателя данными социального, культурного и исторического характера, приводит многочисленные цитаты из греческих и европейских литературных произведений, сообщает о новинках и технических достижениях (например, описывает полеты на аэроплане и гидроплане) и, подмечая мелкие и, казалось бы, несущественные детали, оживляет описания юмористическими зарисовками [22]. Так, например, описываются загородные кафе для отдыхающих: 
Ох уж эти загородные рестораны! Сколько сотен их, сколько тысяч? Вот статистика, которую никто и не думал вести, а между тем это было бы интересно - и заставило бы сделать целую кучу выводов, в том числе и социального характера... В любом случае совершенно точно, что таких ресторанов без счета. На пути их вам встретится больше, чем улиток после дождя, куда бы вы ни подались на автомобиле. Ни на побережье Аттики, ни на берегах Средиземноморья вообще нет такого забытого богом места, где бы не нашелся на вашу беду такой «ресторан»... Всю дорогу до Варкизы вы только и делаете, что встречаете нарисованную на стенах домов рекламу «Бар “Трежоли”, Варкиза». Бар в Варкизе, да еще и «трежоли»! Какой приятный сюрприз, говорите вы себе. Едете туда, сбиваетесь с ног в поисках этого самого бара и в конце концов обнаруживаете, что разрекламированный «бар» - не что иное, как крытая сухими сосновыми ветками крошечная хижина, отчаянно похожая на Ноев ковчег, потому что внутри него в тесноте, да не в обиде живут сам хозяин заведения, его семейство, куры, собака, бессчетное множество мух, несколько пустых жестянок из-под бензина, две бочки, жаровня и прочие обитатели, одушевленные и неодушевленные. Естественно, единственное, что вас ждет в этом «трежоли» - рецина, которую подают то как выдержанное, то как молодое вино и которая от этого не становится менее отвратительной [3I, с. 27].

Таким образом, как кажется, с точки зрения читателя «истинной литературой» прозу К. Ураниса делает изящный и легко узнаваемый стиль, увлекательная манера изложения, разнообразие тем и преобладание в тексте «я» повествователя, которое определяет тематику заметок и заставляет автора смотреть на изображаемое через призму собственного субъективного восприятия. Развлекательный характер некоторых зарисовок уравновешивается эпизодами серьезного размышления о «вечных вопросах» или актуальных проблемах эпохи.

Те же черты можно обнаружить и в произведениях Казандзакиса-путешественника. Как и для прозы К. Ураниса, для записок Н. Казандзакиса характерна некоторая обрывочность, хаотичность впечатлений, что, безусловно, отчасти объясняется историей их публикации и особенностями самого жанра, выросшего из дневниковых записей и потому допускающего фрагментарность. В то же время, в отличие от травелогов К. Ураниса, 
в заметках Н. Казандзакиса легко прослеживается внутренняя структура, в основе которой лежит либо географический, либо тематический прин-

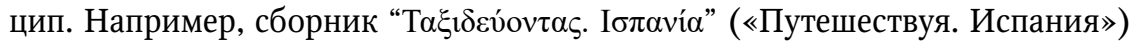
построен в соответствии с первым принципом: каждая глава повествует о том или ином испанском городе, а их последовательность соответствует

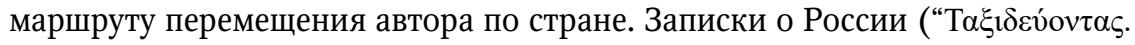
Роvбі́ $\alpha$, «Путешествуя. Россия»), напротив, в основном сгруппированы тематически, о чем свидетельствуют названия отдельных глав («Русская литература», «Красная армия», «Красное искусство», «Рабочие и крестьяне» и т. д.). Объединение обоих принципов характерно, например, для записок о

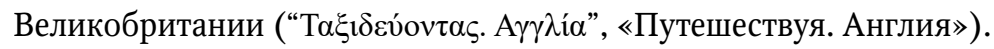

Принципиально различны, однако, мотивы К. Ураниса и Н. Казандзакиса и цели, которые перед собой ставит каждый из авторов. Путешествие, воспринимаемое К. Уранисом как бегство, для Н. Казандзакиса является, напротив, необходимостью, необоримой потребностью, высшей силой, толкающей к поискам и познанию. Сила эта персонифицируется в

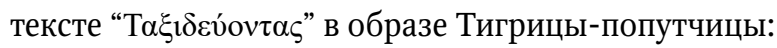

Тигрица-попутчица, хоть и ненавидела меня, была со мной во всех моих путешествиях... И когда, нагруженные трофеями, израненные, мы возвращаемся в нашу прохладную тихую келью, Тигрица молча раздирает кожу на моем затылке... обвивается вокруг моего черепа, погружает когти в мой мозг - и мы думаем о том, что видели, и том, что нам предстоит еще увидеть... Боже, что это за счастье - жить, видеть, играть с великой Тигрицей и не бояться! [27, с. II-I2].

То, что для К. Ураниса стало бы поводом для шутки, иронии, воспринимается Казандзакисом совсем иначе - драматически и с пафосом. Любая незначительная деталь рассматривается им как символ, как необходимый элемент круговорота истории. Его путевые заметки пронизаны ощущением «начала конца», поскольку фиксируют многочисленные потрясения и катастрофы первой половины XX в. (Казандзакис впервые оказался в России через несколько лет после революции I9I7 г., в Англии - в самом начале Второй мировой, в Испании - в разгар гражданской войны, в Италии после прихода к власти Муссолини), которые, с точки зрения писателя, 
являются предвестниками смены эпох, наступления новой эры в истории человечества.

В этом контексте путешествие рассматривается Н. Казандзакисом как поиск истины, способ приобретения драгоценного опыта - но и как своеобразный долг и ясно выраженная гражданская позиция любого думающего человека:

От времени, в которое мы живем, зависит так много, что любая ложь или замалчивание правды было бы актом оскорбления [28, с. 9].

Смотреть незамутненным взглядом - не замутненным ни ненавистью, ни любовью - на современность, признавать и достоинства, и подлость, видеть и свет, и тьму, которые здесь, на Земле, составляют любой живой организм, будь то человек или идея, - одним словом, быть свободным значит встать на путь духовного подвижничества [29, с. 7].

Говоря о поиске истины и незамутненности взгляда наблюдателя, Казандзакис как будто провозглашает отказ от диктата субъективизма и возвращается к литературной традиции XVII-XVIII вв., предполагавшей, что и автор путевых заметок, и его читатели верят в полное соответствие описываемого действительности. Этот принцип сформулирован им, в частности, в заметках о России: «Я рассказываю правду такой, какой видел ее своими глазами» [28, с. 9].

Это подтверждается также и обилием сведений социально-политического, культурного, исторического, географического характера, содержащихся в сборниках путевых заметок. Например, рассказывая о положении женщин, национальном вопросе или пенитенциарной системе в России после Октябрьской революции, Н. Казандзакис приводит относящиеся к делу статистические данные, цитаты из прессы, научных и публицистических работ; рассуждения о русской литературе сопровождаются многочисленными отрывками прозаических и поэтических текстов.

Эта мнимая объективность, однако, разрушается самим автором. Как и в прозе К. Ураниса, в записках Н. Казандзакиса очевидно стремление наполнить собственным, «личным» содержанием традиционный для туриста обзор достопримечательностей. Максимально нейтральные описательные или насыщенные информацией фрагменты сменяются эпизодами само- 
погружения и самоанализа, мимолетными впечатлениями, отвлеченными рассуждениями. Подобно заметкам К. Ураниса, описания у Н. Казандзакиса часто являются лишь поводом, внешним стимулом для нескончаемого потока образов, ассоциаций и размышлений. Например, описание боя быков в Испании становится для автора поводом для рассуждений о природе божественного, любви и архаических языческих культах Средиземноморья [30, с. I24-I32], а прогулка по древней Олимпии превращается в философские поиски места Греции в современной западной цивилизации [27, с. 243].

Несмотря на декларируемую Н. Казандзакисом объективность и якобы полное соответствие действительности, в нарушение всякого правдоподобия он населяет путевые заметки несуществующими персоналиями [г9, с. 6-7] или описывает как реальные свои воображаемые встречи с давно умершими людьми (Шекспир, Ницше), что также более походит на акт самопогружения или самогипноза, нежели на описание реальных событий.

Подведем итог сказанному выше. Утверждения греческой критики о том, что путевые заметки Н. Казандзакиса являются первым и лучшим образцом этого жанра, не находят подтверждения, если рассматривать цикл «Т $\alpha \xi 1 \delta \varepsilon v ́ o v \tau \alpha \varsigma$ («Путешествуя») не изолированно, а в более широком контексте. В частности, обнаруживается, что литература о путешествиях на греческом языке имеет длительную историю и к XX в. была представлена достаточно широко, в том числе произведениями таких писателей, как Г. Дросинис, А. Каркавицас и Д. Викелас, которых с трудом можно отнести к числу авторов «второго ряда».

Первенство и главенствующая роль Н. Казандзакиса в развитии жанра путевых заметок в ХХ в. представляются сомнительными и в том случае, если не принимать во внимание диахронический аспект. В частности, выше рассматривались путевые заметки К. Ураниса, которому на несколько лет раньше, чем Н. Казандзакису, удалось найти баланс между индивидуальным и личным, объективным и субъективным в прозе о путешествиях и при этом сохранить изящную литературную форму.

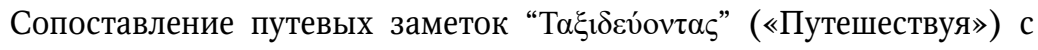
записками К. Ураниса показывает, что многие особенности прозаического жанра путешествия, которые современная греческая литературная критика склонна считать находками Н. Казандзакиса и достоинствами его индивидуального стиля, были разработаны до него. Фрагментарность, обрывоч- 
ность повествования, сочетание в нем реального и ирреального, насыщенность текста фактами, цитатами и деталями при отсутствии «описаний ради описания», взаимопроникновение субъективного и объективного при организующей роли «я» автора-рассказчика, узнаваемый авторский стиль - все эти черты обнаруживаются и в записках К. Ураниса.

Признание этого факта нисколько не умаляет художественных достоинств путевых заметок Н. Казандзакиса, а позволяет более корректно оценить их и существенно обогащает современные представления о развитии жанра путешествия в новогреческой литературе. 


\section{Список литературы Исследования}

I Литературный энциклопедический словарь. М.: Сов. энциклопедия, I987· 75I c.

2 Майга А.А. Африка во французских и русских травелогах (А. Жид и Н. Гумилев): автореф. дис. ... канд. филол. наук. СПб., 2ог6. 2г с.

3 Мантова Ю.Б. Путешествия в византийской агиографии XI-XII вв.: особенности художественного воплощения: автореф. дис. ... канд. филол. наук. М., 20I6. I7 с.

4 Петрунина О.Е. Греческая нация и государство в XVIII-XX вв. М.: КДУ, 2016. $744 \mathrm{c}$.

5 Шачкова В.А. «Путешествие» как жанр художественной литературы: вопросы теории // Вестник ННГУ. 2008. № 3. С. 277-28I.

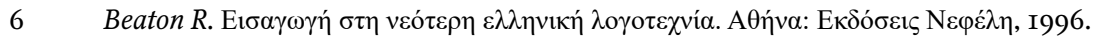
$457 \mathrm{p}$.

7 Bien P. Kazantzakis. Politics of the Spirit. Princeton; Oxford: Princeton University Press, 2007. Vol. 2. 640 p.

8 Blanton C. Travel Writing: The Self and the World. New York; London: Routledge, 2002. $148 \mathrm{p}$.

9 Dimadis K.D. Las cronikas periodisticas de Nikos Kazantzakis sobre la Guerra civil espanola y su obra Vaiando. Espana // Olga Omatos (ed.). Tras las huellas de Kazantzakis. Granada: Athos - Pergamos, I999. P. I05-II7.

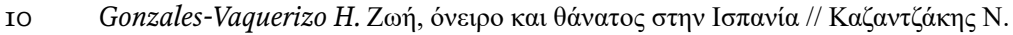

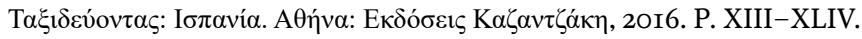

II Huenen $R$. Le récit de voyage : l'entrée en littérature. Études littéraires. I987. 20 (I). P. 45-6I.

Hutcheon L. A poetics of postmodernism: History, Theory, Fiction. London, New York: Routledge, 2002. 284 p.

I3 Teleioni E. Nikos Kazantzakis' Travel Writings on England // Rosetta Journal. 2013. I2.5. P. 79-83.

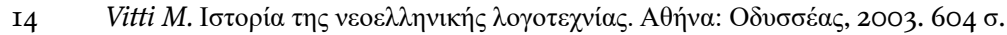

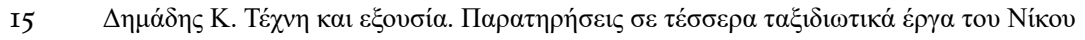

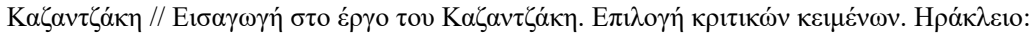

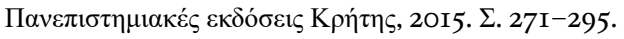

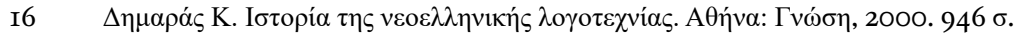

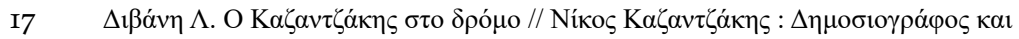

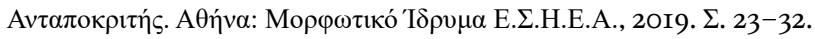

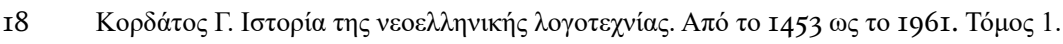

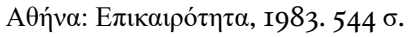

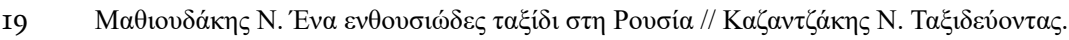

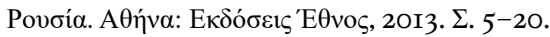




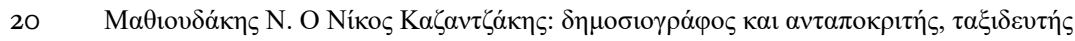

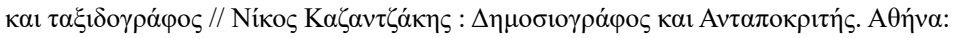

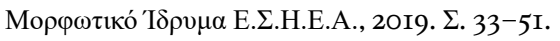

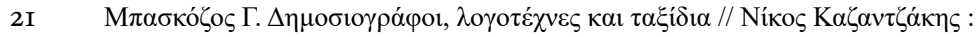

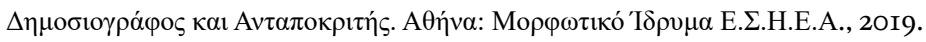
¿. II-I9.

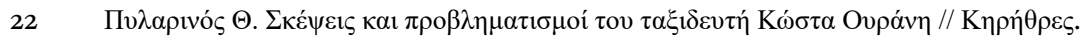
URL: http://kirithres.blogspot.com/2015/o6/blog-post_I2.html (дата обращения: O2.I2.2O2O).

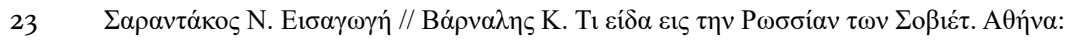

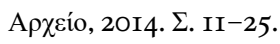

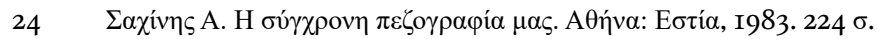

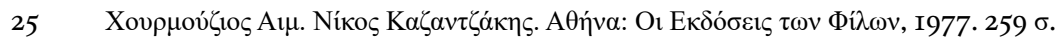

\section{Источники}

26 Казандзакис Н. Из путешествий (из книги «Пелопоннес») // Падающий зиккурат. Альманах. СПб.: Инапресс, І995. С. 5-15.

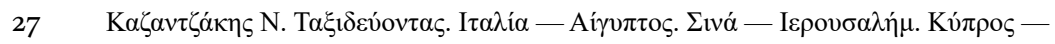

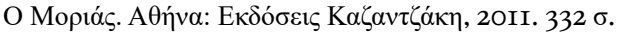

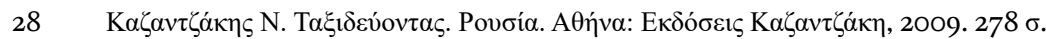

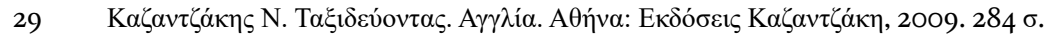

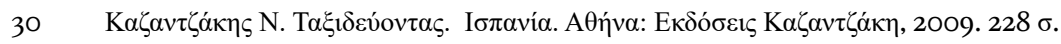

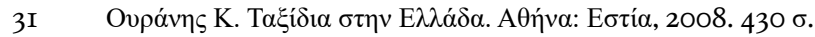




\section{References}

I Literaturnyi entsiklopedicheskii slovar' [Encyclopaedical Dictionary of Literary Terms]. Moscow, Sovetskaia entsiklopediia Publ., I987.75I p. (In Russ.) Maiga, A.A. Afrika vo frantsuzskikh i russkikh travelogakh (A. Zhid i N. Gumilev [Africa in French and Russian Travel Writings (A. Gide and N. Gumilev): PhD Thesis, Summary]. St. Petersburg, 20I6. 2I p. (In Russ.)

3 Mantova, Iu.B. Puteshestviia v vizantiiskoi agiografii XI-XII vv.: osobennosti khudozhestvennogo voploshcheniia [Travelings in Byzantine Hagiography of the $I I^{\text {th }}-I 2^{\text {th }}$ Centuries: Peculiarities of Literary Implementation: PhD Thesis, Summary]. Moscow, 20I6. I7 p. (In Russ.)

4 Petrunina, O.E. Grecheskaia natsiia i gosudarstvo $v$ XVIII-XX vv. [Greek Nation and the State in the $I 8^{\text {th }}-20^{\text {th }}$ Centuries]. Moscow, KDU Publ., 20I6. 744 p. (In Russ.)

5 Shachkova, V.A. “Puteshestvie' kak zhanr khudozhestvennoi literatury: voprosy teorii” [“'Traveling' as a Literary Genre: Theoretic Issues”]. Vestnik NNGU, no. 3, 2008, pp. 277-28I. (In Russ.)

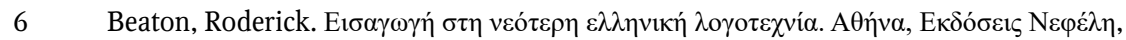
I996. 457 p. (In Greek)

7 Bien, Peter. Kazantzakis. Politics of the Spirit. Vol. 2. Princeton, Oxford, Princeton University Press, 2007. 640 p. (In English)

8 Blanton, Casey. Travel Writing: The Self and the World. New York, London, Routledge, 2002. I48 p. (In English)

9 Dimadis, Konstantinos. "Las cronikas periodisticas de Nikos Kazantzakis sobre la Guerra civil espanola y su obra Vaiando. Espana”. Omatos, Olga, editor. Tras las huellas de Kazantzakis. Granada, Athos - Pergamos, I999, pp. I05-II7. (In Spanish)

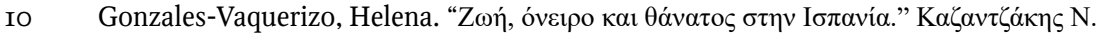

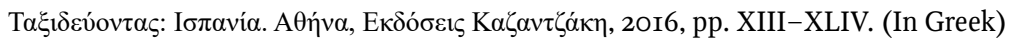

II Huenen, Roland de. “Le récit de voyage: l'entrée en littérature." Études littéraires, no. 20 (I), I987, pp. 45-6I. (In French)

I2 Hutcheon, Linda. A Poetics of Postmodernism: History, Theory, Fiction. London, New York, Routledge, 2002. 284 p. (In English)

I3 Teleioni, Eleftheria. "Nikos Kazantzakis' Travel Writings on England." Rosetta Journal, no. I2.5, 2013, pp. 79-83. (In English)

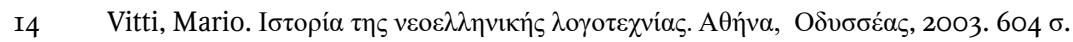
(In Greek)

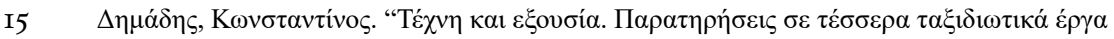

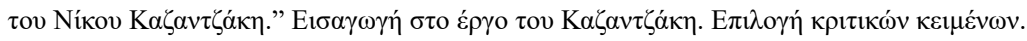

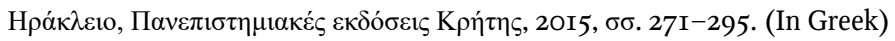

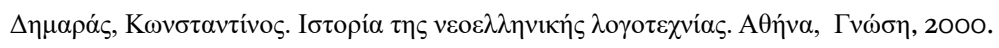
$946 \sigma$. (In Greek) 


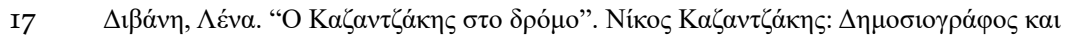

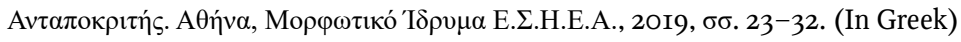

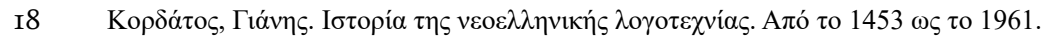

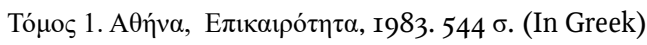

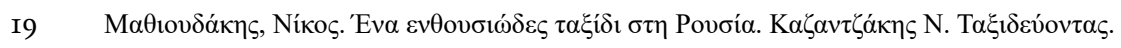

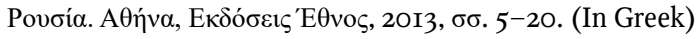

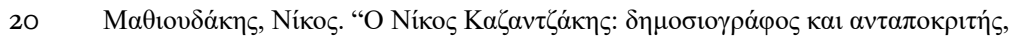

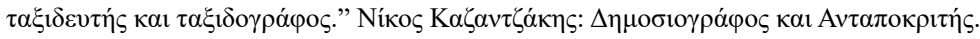

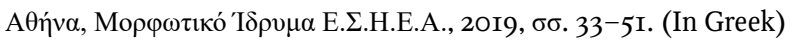

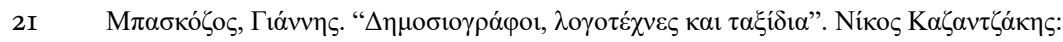

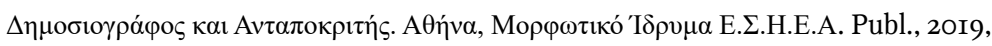
бб. II-I9. (In Greek)

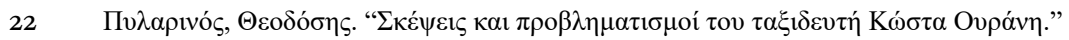

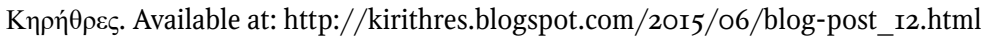
(Accessed o2 December 2020). (In Greek)

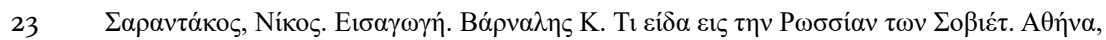

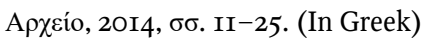

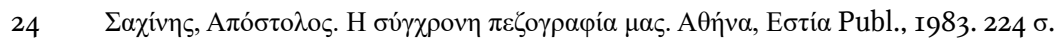
(In Greek)

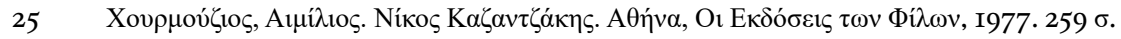
(In Greek) 